\section{Justice not seen to be done?}

\section{Washington}

A vision researcher charged by the National Institutes of Health (NIH) with scientific plagiarism, and facing debarment from all federal funds is, not surprisingly, attempting to fight the decision. But he claims that, having been given no real chance to defend himself early on in the proceedings, he may now be the victim of a cursory justice against which he has no legal right of redress.

Two months ago, an NIH investigatory panel declared that C. David Bridges, a vision researcher now at Purdue University, had plagiarized material from a paper sent to him for review, and then published it as his own, in the journal Science (see Nature 340, 173; 1989). NIH terminated Bridges' current grants and excluded him from service on any peer-review or advisory bodies, actions which the then director of NIH, James B. Wyngaarden, could take by endorsing the panel's recommendations with his signature. But the panel also recommended that Bridges be debarred from receiving federal funds from any source. This NIH have not the power to do, and the recommendation was passed to the Deputy Assistant Secretary for Procurement Assistance and Logistics in the Department of Health and Human Services, who was also to determine the period of debarment. On 18 August, Bridges received a letter from James F. Trickett, DHHS Deputy Assistant Secretary for Management and Acquisition, notifying him that debarment for a period of five years was being considered, and giving him 30 days to respond.

Bridges claims that Trickett's letter give him "no clear idea" of what the next step in the process might be. But Les Ribnik, clerk to George M. Bishop, Bridges' lawyer, said that the letter included copies of the appropriate sections of the Code of Federal Regulations, according to which the debarment procedure is conducted. On 13 September, Bishop wrote to Trickett with a lengthy and detailed response to the charges made by the NIH panel, and requesting a "trial type hearing".

Whatever the next step may be, it will probably take most of the participants into uncharted waters. A "trial type hearing", in which the two sides would be able to cross-examine each other, is not the kind of appeal hearing that would normally be given in such a case. Because there is no constitutional or other elementary legal right to receive federal research funds, suspension of an NIH grant, for example, comes under the jurisdiction of administrative law, not civil law, and a debarment hearing would be conducted somewhat in the manner of a civil hearing in some European countries, in which a presiding judge asks all the questions and the lawyers for each side are relatively quiet.

But Bridges' complaint is that he has not so far had any opportunity to question the evidence supplied against him, and will not get an opportunity if administrative law takes its course. Indeed, he believes it is entirely within Trickett's discretion whether to grant a hearing on the debarment or not.

Bridges sees himself so far as the victim of dealings that, although entirely legal, are of questionable virtue. When the NIH panel met for two days in Chicago to interview many of the protagonists in the case, Bridges and his lawyer were prevented, despite repeated requests, from having a transcript of the proceedings made, even at their own expense. A preliminary report by the panel was given to Bridges for his response, but nevertheless, he says, he still does not know on what or whose testimony some of the charges were based.

Much of Bridges' rebuttal of the charges against him is an amplified version of his criticisms of the preliminary NIH report which, he says, were not satisfactorily answered in the panel's final version. The NIH review concluded that Bridges could not, as he maintains, have done the crucial experiments before he received a paper from Robert Rando et al. for review, because he did not until later acquire sufficient supplies of a tritium-containing reagent, with a restricted shelf-life, essential for the work. Bridges' response sets up a history by which, if earlier supplies of the tritiated reagent were carefully husbanded, and smaller quantities used than Bridges' former technician told the panel, some experiments could have been done before fresh supplies were ordered.

The NIH panel also argues that Bridges suddenly started using the experimental conditions and reagent mixes specified by Rando et al., without any precedent in his earlier laboratory work. Bridges' response is to pick out elements of his previous experiments and draw a thread of reasoning which pulls them together in the later, disputed work.

Bridges maintains that had he been able to make this case to the review panel earlier, and to see and criticize the evidence laid against him, the whole affair would not have got this far. And although he has now assembled an argument which he says would dispel the charge of plagiarism, he fears he will not get the chance to present it. But Trickett, the DHHS official from whom Bridges is waiting to hear, says the right to appeal is one he "insists on", and promises that if Bridges has a case it will be heard. laboratory

Paris

ThE Squibb Corporation, the US pharmaceutical company, is to spend more than FF280 million ( $\$ 43$ million) on a basic research initiative in molecular biology at the Université Louis Pasteur in Strasbourg, on the Franco-German border. The deal includes construction of a FF154-million laboratory and support for about $\mathbf{5 0}$ scientists for the next seven years. In return, the company will have the right to claim up to half of the projects carried out within the laboratory as theirs, with the option of an exclusive world licence should patentable results emerge.

The 10,000 square metre building should be completed in 1992, on a site in Strasbourg's suburban science park. Under the arrangement with Squibb, if the present 12year contract is not renewed, the laboratory will remain at the disposal of researchers and after 50 years will revert to the university.

At present, the university's molecular biology laboratory has about 160 staff, mostly employed on permanent contracts by either the state medical research organization, INSERM, or the national science research centre (CNRS). This, says Pierre Chambon, who will direct the new laboratory, means that it is difficult to have a turnover of young researchers. Now, with running costs of around FF18 million per year provided by Squibb for the first seven years, some twenty-five young scientists will be recruited on five-year contracts. To allow this arrangement to work, Squibb has agreed to renew its funding in five-year cycles.

Under the agreement, researchers will remain free to choose their research themes, without interference from Squibb. The work is likely to prove productive for the drugs company, however, as Chambon explains: "the kind of basic research we do, for example on regulatory proteins, will be useful for the design of new drugs over the next 10 to 15 years". The arrangement also does not preclude other companies from taking out licences on results in which Squibb has no interest. Chambon is confident that publication of important results will not be affected by the deal, with a maximum delay of around $\mathbf{4 5}$ days in the case of a patent application. Where a licence is taken out, Squibb will pay royalties to CNRS and INSERM.

In recent years, there have been several other examples of pharmaceutical giants, such as Hoechst and Bristol-Myers (now merged with Squibb), investing in basic research. And last July, construction began on a \$32-million neuroscience research laboratory at the University of Oxford under a similar 12-year arrangement with Squibb.

Peter Coles 